\title{
AUSZTENITES KORRÓZIÓÁLLÓ ACÉL SZEMCSEHATÁRMENTI KORRÓZIÓRA VALÓ HAJLAMÁNAK ELEMZÉSE FIZIKAI SZIMU- LÁCIÓVAL
}

\author{
Dobosy Ádám \\ adjunktus, Anyagszerkezettani és Anyagtechnológiai Intézet \\ 3515 Miskolc, Miskolc-Egyetemváros, e-mail: metda@uni-miskolc.hu \\ Gáspár Marcell \\ docens, Anyagszerkezettani és Anyagtechnológiai Intézet \\ 3515 Miskolc, Miskolc-Egyetemváros, e-mail: gasparm@uni-miskolc.hu \\ Nagy Gyula \\ c. egyetemi tanár, Anyagszerkezettani és Anyagtechnológiai Intézet \\ 3515 Miskolc, Miskolc-Egyetemváros, e-mail: metnagyg@uni-miskolc.hu
}

\begin{abstract}
Absztrakt
Mint ismeretes, az ausztenites korrózióálló acélok, ha azok karbontartalma meghaladja a 0,03-0,04\%ot, nagyobb hömérsékletröl lassan hütve, vagy 500 - $900{ }^{\circ} \mathrm{C}$ hömérséklet közben hön tartva, nem lesznek homogén szövetszerkezetüek. Az ausztenit mellet számos intermetallikus vegyület válik ki, amelyek közül a szemcsehatármenti korrózió kialakulása szempontjából a $M_{23} C_{6}$ karbid kiválása a meghatározó. A kiváló nagy krómtartalmú (kb. 65\%) fázis környezetében az ausztenit Cr tartalma 10,5\% alá csökkenhet, igy az acél kristályközi korrózióra hajlamossá válhat. A szemcsehatármenti korrózióra hajlamos ausztenites korrózióálló acélok esetén a hegesztési höfolyamat hatására is kialakulhat a nem kívánt kiválás. Az egyes ausztenites korrózióálló acélok érzékenységének jellemzése érdekében ún. szenzibilizációs diagramokat célszerü meghatározni, amelyeknél a höntartás hömérséklete és ideje függvényében a karbidok elhelyezkedési, elöfordulási területeit jelenitik meg. Tekintettel arra, hogy a hegesztés höciklusa jelentösen különbözik az állandó hömérsékletü kezelésnél alkalmazottól, a szemcsehatármenti korróziós hajlamot a hegesztési höfolyamat paramétereinek függvényében célszerü elemezni. Jelen kutatómunkában fizikai szimulációval elöállított hegesztési höciklus(ok)nak kitett próbatesteken (X5CrNi18-10, 1.4301) végeztünk kisérleteket egy Gleeble 3500 típusú berendezésen, amelynek során különbözö maximális hömérsékleteket létrehozva, változó lehülési profilokat vizsgáltunk. A vizsgálati eredmények felhasználásával különválasztottunk néhány olyan hegesztési höciklust, amelyek alkalmazása esetén bekövetkezhet szemcsehatármenti korrózió, illetve az elkerülhetö a vizsgált ausztenites alapanyagon.
\end{abstract}

Kulcsszavak: ausztenites acél, szemcsehatármenti korrózió, szenzibilizációs diagram, Gleeble, fizikai szimuláció

\begin{abstract}
As known, the austenitic stainless steels, if their carbon content exceeding 0,03-0,04\%, with slow cooling from higher temperature, or tempering between $500-900{ }^{\circ} \mathrm{C}$, a non-homogeneous microstructure evolved. Addition to the austenite, a number of intermetallic compounds can be precipitated, among these the $M_{23} C_{6}$ carbide is the most determining, in terms of intergranular corrosion. Around the pre-
\end{abstract}


cipitated, high chromium content (approximately 65\%) phase, the austenite Cr content could be decreases under 10,5\%, so the steel became sensitive to intergranular corrosion. This undesirable effect could be evolved during the welding heat cycle, in case of austenitic steels with intergranular corrosion sensitivity. The sensitivity properties of these austenitic stainless steels can be described by sensitivity diagrams, which can display the location and occurrence area of carbides, as a function of the holding temperature and time. Given that, the welding heat cycle significantly different from the constant tempering heat treatment, the sensitivity of austenitic stainless steels should be analysed in the fucniton of the different parameters of welding heat cycle. In this research work, experiments were done on test specimens with physical simulated welding heat cycles on a Gleeble 3500 equipment, where different maximum temperatures were used, alongside with variable cooling profiles. With the gained test results the welding circumstances were determined, which can cause intergranular corrosion in the tested austenitic steels.

Keywords: austenitic steel, intergranular corrosion, sensibility diagram, Gleeble, physical simulation

\section{Bevezetés}

Mint ismeretes az ausztenites korrózióálló acélok, ha azok karbontartalma meghaladja a 0,03-0,04\%-ot (a szokásos $\mathrm{C}$ tartalom 0,03-0,1\% között van), nagyobb hőmérsékletről $\left(1000^{\circ} \mathrm{C}\right.$ feletti homogén ausztenites állapothoz tartozó hőmérsékletről) lassan hütve, vagy 500-900 ${ }^{\circ} \mathrm{C}$ hömérséklet közben hőntartva, nem lesznek homogén szövetszerkezetüek. Az ausztenit mellet számos intermetallikus vegyület válik ki, amelyek közül a szemcsehatármenti korrózió kialakulása szempontjából az $\mathrm{M}_{23} \mathrm{C}_{6}$ típusú karbid kiválása a meghatározó. A kiváló nagy krómtartalmú (átlagosan 65\%) fázis környezetében az ausztenit Cr tartalma az első rezisztencia határ (10,5\%) alá csökkenhet, így az acél kristályközi korrózióra hajlamossá válhat. Az MSZ EN 10020 és MSZ EN 10088 szabványok ezt a krómtartalmat adják meg a rozsdamentes acélok alsó határaként.

Az egyes ausztenites korrózióálló acélok szemcsehatármenti kiválásra való érzékenysége, szenzibilizációja, jelentős mértékben függ az acél karbontartalmától. Tekintettel arra, hogy a krómkarbid kiválása diffúziós folyamat, keletkezését, kialakulását döntően befolyásolja a hőntartás hőmérséklete és ideje. A szemcsehatármenti korrózióra hajlamos ausztenites korrózióálló acélok esetén a hegesztési hőfolyamat hatására is kialakulhat a nem kívánt kiválás. Ezért nemcsak a felhasználási körülmények, de a hegesztés szempontjából is meghatározó a szenzibilizáció.

Az egyes ausztenites korrózióálló acéloknak ismerni kell az érzékenységét. Ennek érdekében szenzibilizációs diagramokat célszerü meghatározni, amelyeknél a hőntartás hőmérséklete és ideje függvényében a karbidok elhelyezkedési, előfordulási területeit jelenítik meg. Mivel a kiválási folyamatot a diffúzió irányítja, a hőmérséklet és annak változása döntő hatással van a karbidok kialakulására [1] [2].

Tekintettel arra, hogy a hegesztés höciklusa jelentősen különbözik az állandó hőmérsékletủ kezelésnél alkalmazottól, célszerü elemezni a $\mathrm{M}_{23} \mathrm{C}_{6}$ karbid kiválási folyamatát és az ausztenites korrózióálló acélok érzékenységének kialakulását a hegesztési hőfolyamat paramétereinek függvényében. A vizsgálatokat a nehezen kézben tartható, kevésbé reprodukálható hegesztett kötések helyett a hegesztési hőfolyamatot megvalósító hőhatásnak (szimulált hegesztési hőfolyamat) kitett próbatesteken célszerü tanulmányozni. Ilyen kísérletek elvégzésére alkalmas a Gleeble 3500 fizikai szimulátor, amellyel a különböző paraméterek hatását széleskörüen lehet vizsgálni.

A fizikai szimuláció segítségével előállított hőhatásoknak a különböző hegesztési paraméterekkel készült kötések hőhatásövezeteiben kialakulónak kell megfelelniük. A különböző maximális hőmér- 
sékletről eltérő lehülési profillal hűtött próbatesteken az esetleges karbidkiválás következtében kialakuló korróziót megfelelő feltételek mellett kell előidézni, majd kimutatni. E vizsgálati eredmények felhasználásával meghatározhatók azok a hegesztési paraméterek, amelyek alkalmazása esetén bekövetkezik szemcsehatármenti korrózió.

\section{A korrózióálló acélok jellemzői}

A korrózióálló acélok a több mint egy évszázados fejlődésük során jelentős mértékben módosultak, fejlődtek, korszerü korrózióálló acélfajták jelentek meg. Felhasznált mennyiségük folyamatosan növekszik. A korrózióállóság egy viszonylagos fogalom, mert a korrodáló közegen túl számos további tényező (hőmérséklet, kísérő elemek fajtája stb.) befolyásolja a károsodást [3]. Az egész folyamat hajtóenergiája az a szabad entalpia különbség, ami a fémek, ötvözeteik és a korrózió folyamán kialakuló vegyületeik között van. A korrózió megjelenési formája rendkívül sokféle [4].

A korrózióálló acélok közös jellemzője, hogy felületükön oxidhártya alakul ki, amelynek jól tapadónak, tömörnek kell lenni. Az acélok felületén ilyen passzív oxidhártya keletkezik, ha a krómtartalmuk 10,5\%-nál nagyobb.

Szövetszerkezetük alapján a hagyományos korrózióálló acéloknak három változata terjedt el. A ferrites krómacélok 16-18\% közötti Cr tartalommal rendelkeznek és karbontartalmuk általában 0,100,12\% közötti. A martenzites korrózióálló acélok 12-18\% krómot tartalmaznak, a karbontartalmuk széles tartományt fog át, 0,15-1,20\%. A krómot tartalmazó acélokat nikkellel ötvözve szövetszerkezetük szobahőmérsékleten is ausztenites lehet [5].

A felhasznált korrózióálló acélok közel 90\%-kát teszik ki az ausztenites korrózióálló acélok, vagyis a legszélesebb körben használják fel azokat [6]. A korrózióálló acélok közül a legjobb a korrózióállóságuk, a hegeszthetőségük is kiváló. Hátrányuk a kis folyáshatáruk, ugyanakkor nagy az alakváltozó képességük, és rendkívül szívósak. A hagyományos korrózióálló acélok krómot (16-26\%), nikkelt (8$22 \%$ ) és mellettük további ötvözöket is tartalmaznak részben a korrózióállóság növelése érdekében, részben egyéb okokból, például szilárdságnövelés, forgácsolhatóság javítása miatt. Ezen acélcsoport tagjainak karbontartalma általában nem haladja meg a $0,12 \%$-ot, és több évtizedes fejlesztési tendenciája a karbontartalom csökkentése. Ennek csökkentése ugyanis növeli a korrózióállóságot, csökkenti a szemcsehatármenti korrózió kialakulásának veszélyét. Azonban a karbontartalom csökkentésével a folyáshatár is kisebb lesz, és ausztenit képzőként betöltött szerepét más ausztenitképző ötvöző adagolásával, mennyiségének növelésével kell ellensúlyozni. Erre a feladatra a nikkel és a nitrogén adagolása jöhet szóba. Ezért a kis, illetve az extra kis karbontartalmú acélok nagyobb nikkeltartalommal rendelkeznek, ami a nagyobb előállítási költségeken túl, tovább növeli az árukat. A nitrogén adagolása alkalmas más ausztenitképzők részleges helyettesítésére, ezen túl növeli az ausztenit szilárdságát és egyes korrózióval (például lyukkorrózióval) szembeni ellenállását. A jelenleg alkalmazott acélgyártási módszerekkel azonban adagolásának korlátai vannak, mivel légköri nyomáson legfeljebb 0,35-0,40\%ban oldódik az acélban [6] [7].

A karbontartalom csökkentésének további hatása, hogy növekszik a szenzibilizációhoz szükséges inkubációs idő, ezáltal a hütéssel járó technológiai folyamatok elvégzéséhez rendelkezésre álló idő (1. ábra (a)) [8]. A karbontartalom határértéke, amelynél az acél már nem érzékeny a kristályközi korrózióra, szorosan kapcsolódik más ötvöző elemek jelenlétéhez, mint a króm, molibdén, nikkel, nitrogén, mangán, bór, szilícium, valamint titán és nióbium (stabilizált acélok). A nikkeltartalom növelése csökkenti a karbon oldhatóságát, és növeli annak diffúziós képességét. Ez a hatás 20\%-nál nagyobb nikkeltartalom esetén jelentős. Általánosan ajánlott, hogy a 25/20 Cr-Ni acélban a karbontartalom kevesebb 
legyen, mint $0,02 \%$, a szemcsehatármenti korrózióval szembeni ellenállás biztosítása érdekében. A további jelentős ötvözők (molibdén, szilícium) hatását az 1. ábra b) - d) részei szemléltetik.

Ezen acélcsoportot kedvező korróziós tulajdonáguk miatt széles körben alkalmazzák a vegyiparban használatos gépek, berendezések gyártásához, az élelmiszeripari berendezésekhez, a jármügyártásban, továbbá közszükségleti és háztartási cikkek előállításához is. A hazai felhasználás szempontjából meghatározó a jelenleg szabványos X5CrNi18-10 (1.4301) acélminőség, illetve ennek korábbi változata X12CrNi 18-10. A másik két, széles körben felhasznált ausztenites korrózióálló acél az X6CrNiTi18-10 (1.4541), és az X6CrNiMoTi17-12-2 (1.4571) [9].

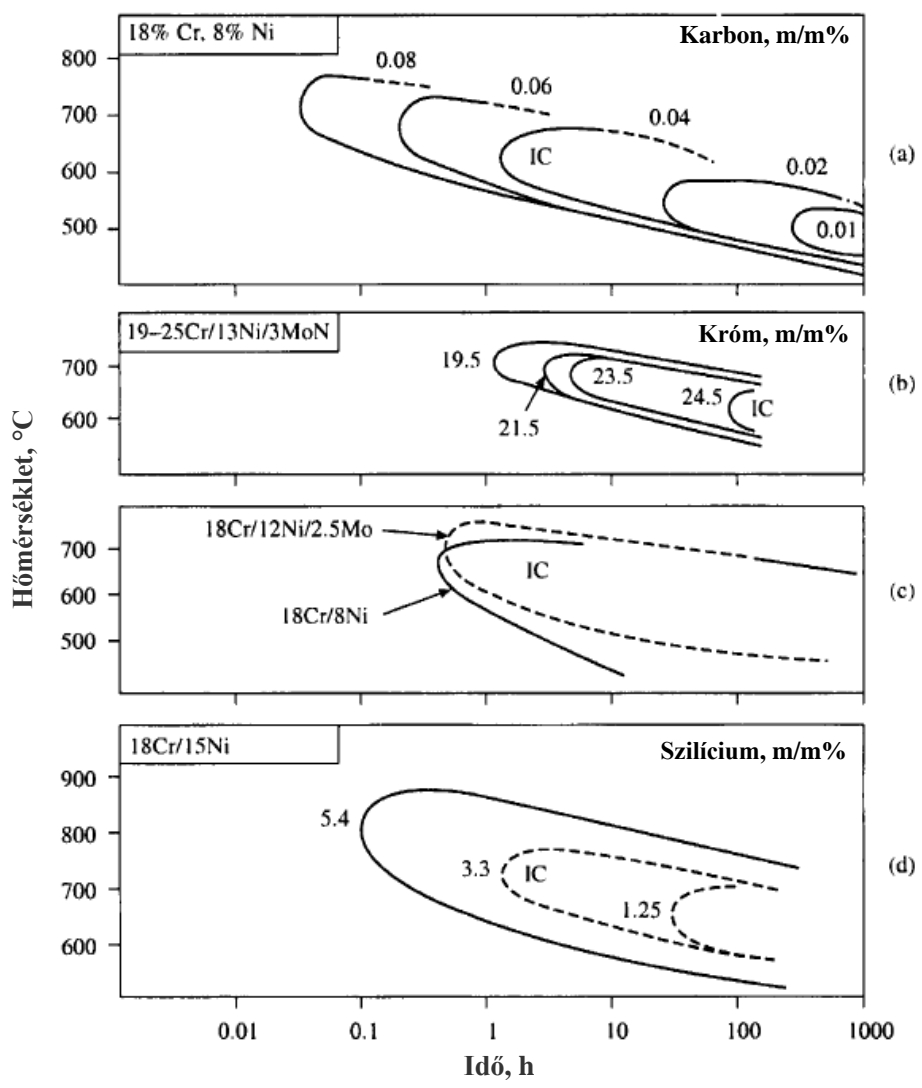

1. ábra. Az ötvözőtartalom hatása a szemcsehatármenti korrózióra és az $M_{23} C_{6}$ típusú kiválásokra: a) karbon, b) króm, c) molibdén, d) szilícium [8].

A kutatásunk során az X5CrNi18-10 (1.4301) acélminőség tanulmányozására fókuszáltunk. Ez az acélminőség, főleg nagyobb karbontartalom esetén, szemcsehatármenti korrózióra jobban hajlamos.

\section{A szemcsehatármenti korrózió jelensége}

Az ausztenites korrózióálló acélok a Fe-Cr-Ni fô alkotókon kívül mindig tartalmaznak karbont, amely részben oldódik a vasban, de karbidokat is képez. A króm erős karbidképző, ezért ezen acélokban krómkarbidok képződésével kell számolni.

Lassú hütés esetén, gyakorlatilag szabad levegőn végrehajtott hütésnél is, illetve megfelelő hőközben $\left(500-900{ }^{\circ} \mathrm{C}\right)$ hőntartva a homogén ausztenitben diffúziós folyamatok játszódhatnak le, kiválások 
jöhetnek létre. Az erősen ötvözött korrózióálló acélokban rendkívül erős a kiválási hajlam, mivel szerkezetük metasabil, illetve instabil. E kiválások diffúzióval végbemenő folyamatok, azokat a hőmérséklet és az idő befolyásolja, szabályozza. A legfontosabb kiválások a következők [10]:

- nagy krómtartalmú komplex karbidok kiválása ausztenit, illetve ferrit szemcsék határain;

- szigma fázis $(\sigma)$ kiválása a ferritben, illetve az ausztenitben;

- khi fázis $(\chi)$ kiválása az ausztenitben és a ferritben;

- Laves fázis kiválása a ferritben és az ausztenitben;

- a $475^{\circ} \mathrm{C}$-os elridegedéshez vezető kiválások;

- nitridek, karbonitridek kiválása;

- delta ferrit kiválása az ausztenitben.

Az előzőekben felsorolt legfontosabb kiválások közül, jelen kutatómunka célkitüzésével összhangban, a nagy krómtartalmú komplex karbidok ausztenit szemcsehatárain megjelenőkkel foglalkozunk. Mivel a keletkezett $\mathrm{M}_{23} \mathrm{C}_{6}$ krómtartalma rendkívül nagy, a kialakulásához szükséges krómot a környező ausztenitből biztosítja, csökkentve annak Cr tartalmát (2. ábra). Amennyiben megfelelő korróziós közeggel kerül érintkezésben ez az acél, benne szemcsehatármenti korrózió alakul ki [11].

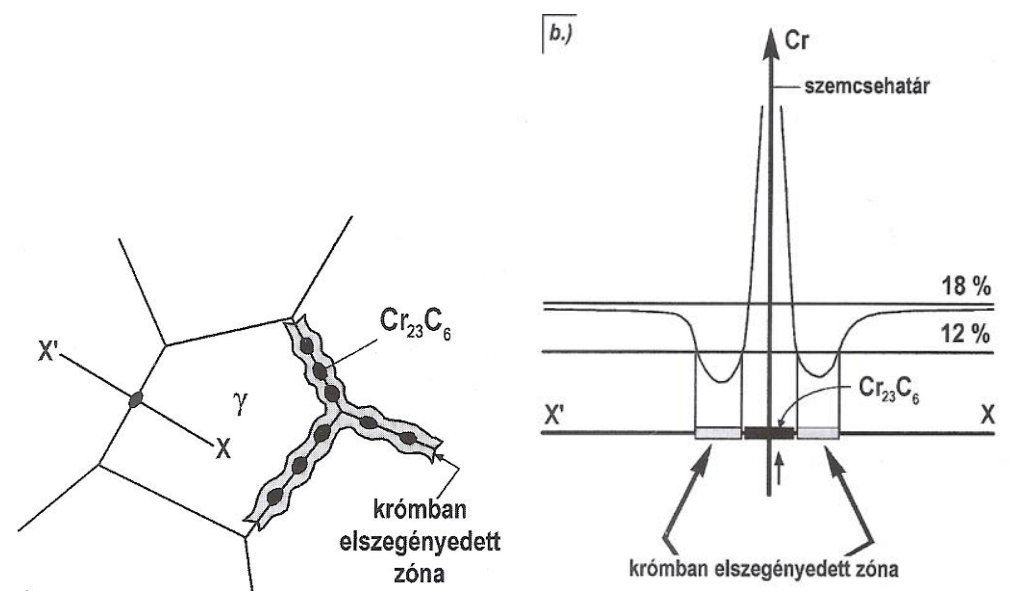

2. ábra. a) Kivált krómkarbidok az ausztenit szemcsehatárán, b) Krómtartalom eloszlása a kivált krómkarbidok mellett [6].

Meg kell jegyezni, hogy a kivált karbidok többsége $\mathrm{M}_{23} \mathrm{C}_{6}$ típusú, felületen középpontos köbös rácsszerkezetü karbid, de a krómon kívül vas, molibdén is jelen lehet az alkotók között. $\mathrm{Az} \mathrm{M}_{23} \mathrm{C}_{6}$ típusú komplex karbidok leggyakoribb előfordulási formái a következők: $\left(\mathrm{Cr}_{16} \mathrm{Fe}_{5} \mathrm{Mo}_{2}\right) \mathrm{C}_{6}$, $\left(\mathrm{Cr}_{17} \mathrm{Fe}_{4,5} \mathrm{Mo}_{1,5}\right) \mathrm{C}_{6}$ molibdént is tartalmazó ötvözetben, illetve $(\mathrm{FeCr})_{23} \mathrm{C}_{6}$ molibdén mentes acélban. $\mathrm{Az}$ ausztenites korrózióálló acélokban $\mathrm{M}_{6} \mathrm{C}$ típusú felületen középpontos köbös rácsszerkezetű karbidok molibdénnel ötvözött, vagy nióbiummal stabilizált acélokban hosszú idő alatt válnak ki. Előfordul még $\mathrm{M}_{7} \mathrm{C}_{3}$ típusú hexagonális rácsszerkezetü karbid is. Végül meg kell említeni a stabilizált ausztenites korrózióálló acélok MC karbidjait (TiC, $\mathrm{NbC})$, illetve karbonitridjeit $\mathrm{M}(\mathrm{C}, \mathrm{N}), \mathrm{Ti}(\mathrm{C}, \mathrm{N})$ és $\mathrm{Nb}(\mathrm{C}, \mathrm{N})$ [1] [12].

Az előzők alapján egyértelmü, hogy a szemcsehatármenti korrózióra hajlamos ausztenites korrózióálló acélok korróziós károsodása megelözhető homogén ausztenites állapotból (1000-1150 ${ }^{\circ} \mathrm{C}$-ról) történő gyors hủtéssel (vízhűtés). Az ilyen módon hőkezelt acélokat azonban nem érheti olyan hőhatás, amely a diffúziós folyamatokat kiválthatja. Amennyiben a 0,03-0,04\%-nál nagyobb karbontartalmú acélokat a későbbi megmunkálás, vagy az üzemelés közben hőhatás éri, 500-900 ${ }^{\circ} \mathrm{C}$ hőmérséklet 
tartományba hevülnek, a szemcsehatárok mentén karbid kiválások jöhetnek létre. Abban az estben, ha az ilyen típusú acélokat a krómnál erősebb karbidképzőkkel ötvözik, akkor a karbon nem $\mathrm{M}_{23} \mathrm{C}_{6}$ karbidot képez. A karbon megkötésére használt ötvöző az ilyen acélokban a titán és a nióbium, a keletkezett karbidok titánkarbid $(\mathrm{TiC})$, illetve nióbiumkarbid $(\mathrm{NbC})$. A megfelelő védelem kialakulásához a titánból az acél karbontartalmának 4-6-szorosa, nióbium esetén 8-10-szerese szükséges. Az ilyen módon készített ausztenites korrózióálló acélokat stabilizált ausztenites acéloknak nevezik [13].

Amennyiben az ausztenites korrózióálló acélok szemcsehatármenti korrózióra hajlamosak ( $\mathrm{C}>0,03 \%$ és nem stabilizáltak), akkor hő hatására a $\mathrm{M}_{23} \mathrm{C}_{6}$ típusú karbidok kiválása bekövetkezhet. Ez egy diffúzió irányította folyamat. A karbidok csiráinak megjelenését és növekedését, illetve a folyamat előrehaladását állandó hőmérsékleten, izotermás körülmények között legegyszerübb tanulmányozni.

A 3. ábra egy 18/8-as Cr-Ni ötvözésü, nem stabilizált acél $\mathrm{M}_{23} \mathrm{C}_{6}$ típusú karbidkiválásra vonatkozó szenzibilizációs diagramját mutatja. Az ábra jól érzékelteti az ausztenites korrózióálló acél karbontartalmának hatását a szenzibilizációra. Amennyiben egy $\mathrm{T}_{1}=700{ }^{\circ} \mathrm{C}$ hőmérsékleten vizsgáljuk a $\mathrm{C}=0,062 \%$ karbontartalmú acél viselkedését megállapíthatjuk, hogy kb. 4 perc elteltével (inkubációs idővel) kezdődik el a $\mathrm{M}_{23} \mathrm{C}_{6}$ csírák kiválása. A diagramból az is megállapítható, hogy az adott hömérsékleten kellően hosszú idő után (kb. 400 óra fölött) megszünik a szemcsehatármenti korróziós hajlam. Ennek oka, hogy a króm koncentrációkülönbség okozta diffúziója következtében a szemcsehatárok mentén a Cr mennyisége növekszik, ismét meghaladja az első rezisztencia határt.

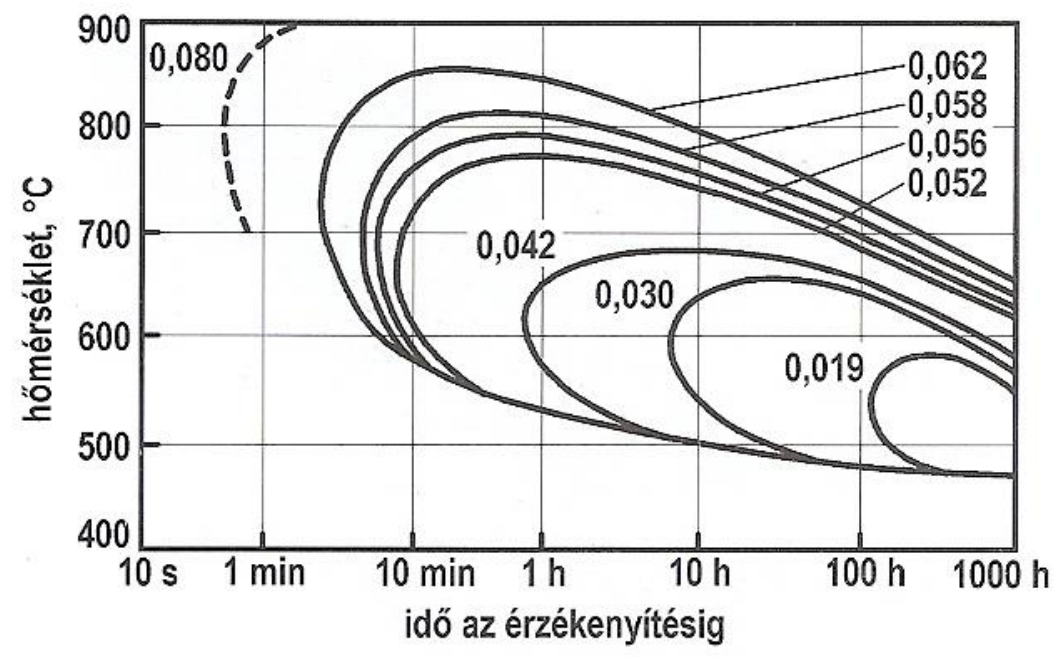

\section{3. ábra. 18/8-as Cr-Ni ötvözésü, nem stabilizált acél $M_{23} C_{6}$ típusú karbidkiválásra vonatkozó szenzibilizációs diagramja [6].}

A szenzibilizációs diagramokat általában izotermás körülmények között határozzák meg. Ennek megfelelően használatuk, olvasásuk, alkalmazásuk is ilyen feltételekkel lehetséges, olyan problémák megoldására, mint a hevítés vagy a feszültségcsökkentés körülményeinek megválasztása, szenzibilizáció elkerülésére. A gyakorlatban alkalmazott hevítési és hütési körülmények az esetek döntő többségében azonban eltérnek az izotermástól, rendszerint folyamatos a hütés. Ilyen esetekben az izotermás viszonyok között felvett szenzibilizációs diagramok alkalmazása erősen korlátozott. Fokozottan érvényes ez a megállapítás a hegesztett ausztenites korrózióálló acélok szemcsehatármenti korróziójának megítélésére [10]. 


\section{Kísérleti eljárás}

\subsection{Kísérleti körülmények}

Az ausztenites korrózióálló acélok szemcsehatármenti korróziós érzékenysége, illetve a korrózió feltételeinek kialakulása számos tényezőtől függ, többek között a hevítési, a hőntartási és a hütési viszonyoktól. Ezért az izotermás körülmények között meghatározott szenzibilizációs diagramok kevésbé használhatók a hegesztési hőfolyamatok hatására kialakuló érzékenyedés kimutatására. Ezen hiányosság feloldása érdekében olyan vizsgálatokat célszerü végezni, amelynek során a hegesztési hőfolyamat paraméterei változásának függvényében határozható meg a $\mathrm{M}_{23} \mathrm{C}_{6}$ karbid kiválás, illetve az általa okozott szemcsehatármenti korrózió bekövetkezése. A hegesztett kötések helyett az érzékenyítésre megbízhatóbb megoldás a hegesztett kötések hőfolyamatainak kitett próbatestek vizsgálata [14].

A szimulált hegesztési hőfolyamat paramétereinek beállítására a Miskolci Egyetem Anyagszerkezettani és Anyagtechnológiai Intézetében rendelkezésre áll egy Gleeble 3500 típusú fizikai szimulátor, amely alkalmazásával a hőhatásövezet különböző sávjainak hőmérséklet változása (hőciklusa) széles tartományban beállítható a gyakorlatban ténylegesen előforduló, alkalmazott hegesztési jellemzőknek, paramétereknek megfelelően. A berendezés lehetővé teszi a hőciklus megvalósítását különböző modellek esetén (például Rykalin, Rosethal, Hannerz), illetve lehetőség van mérési úton, vagy számítással meghatározott hőciklusok alkalmazására is.

A modellezett hőciklusoknál nem indokolt a felhevítés sebességét változtatni, de a maximális hömérsékletet és a hülési sebességet a hegesztési paramétereknek megfelelő széles tartományban kell módosítani. Ez utóbbi jellemzésére a hegesztési területen széles körben alkalmazott 850 és $500{ }^{\circ} \mathrm{C}$

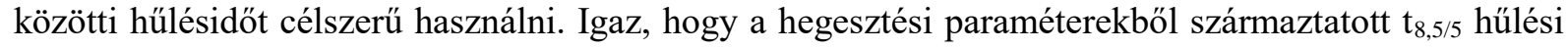
időt a szénacélok edződési hajlamának vizsgálatára szokás alkalmazni (martenzites átalakulás hőmérséklet tartománya), azonban ausztenites acéloknál a szenzibilizáció is döntően ebben a hőmérséklet tartományban jelentkezik, így alkalmas ennek vizsgálatára. További érv ennek a hőmérséklettartománynak az alkalmazása mellett, hogy a berendezést kiszolgáló Quicksim szoftverben is a hőciklusokat alapvetően a t $8,5 / 5$ hủlésidő megadásával javasolt előállítani. A hőfolyamat jellemzői (vonalenergia, illetve fajlagos hőbevitel, előmelegítési/rétegközi hőmérséklet) pedig a $t_{8,5 / 5}$ hülésidő értékéből adott hegesztési feladatra meghatározhatók.

A különböző maximális hőmérsékletről eltérő lehülési profillal hütött próbatesteken az ASTM A262 Practice A, B, C, E and F Intergranular Corrosion Testing [15] szabvány elöírásai szerint célszerü az esetleges karbidkiválás következtében kialakuló korróziót kiváltani, majd hajlító vizsgálattal és mikroszkópi felvételeken kimutatni. Különböző hőciklussal kezelt próbatesteken kialakult, illetve be nem következett korrózió alapján kiválaszthatók azok a paraméterek, hőciklusok, amelyek a szenzibilizációs diagram pontjai lesznek.

Jelen közleménynek nem célja egy teljes hőmérséklet-idő tartomány kritikus határának kijelölése, csupán a módszer alkalmazhatóságát szemléltető eredmények meghatározása, illetve bemutatása.

\subsection{Vizsgált alapanyag}

A vizsgálatainkhoz az X5CrNi18-10 (1.4301) alapanyagot választottuk ki. Ezen acélok kémiai összetételét az 1. táblázat tartalmazza. Az acél kémiai összetétele alapján várhatóan szemcsehatármenti korrózióra hajlamos lesz a nagyobb karbontartalma $(C=0,13 \%)$ miatt. Ez az acélminőség karbont megkötő stabilizáló ötvözőket (titánt, nióbiumot) nem tartalmaz. Az 1.4301 acél lemezvastagsága 3 mm volt. 
1. táblázat. A vizsgált alapanyag vegyi összetétele, tömeg\%-ban

\begin{tabular}{|c|c|c|c|c|c|c|c|}
\hline Jelölés & $\mathbf{C}$ & $\mathbf{S i}$ & $\mathbf{M n}$ & $\mathbf{P}$ & $\mathbf{S}$ & $\mathbf{C r}$ & $\mathbf{N i}$ \\
\hline X5CrNi18-10 (1.4301) & 0,130 & 0,260 & 1,800 & 0,027 & 0,004 & 17,400 & 8,250 \\
\hline
\end{tabular}

\subsection{Fizikai szimuláció}

A hőhatásövezeti höciklusok előállításához Gleeble 3500 termomechanikus fizikai szimulátort (4. a) ábra) és a hozzá tartozó Quicksim szoftvert használtunk. A $3 \mathrm{~mm}$ vastagságú lemezből lemezollón történő darabolással, majd a sorjás élek lemunkálásával alakítottuk ki a 3×25x75 mm méretü próbadarabokat (5. és 6. ábra).

A próbadarab felületének hőmérsékletét a vizsgálatok során termoelem párokkal lehet mérni, amelyeket elözetesen fel kell hegeszteni a felületre. A termoelemek közül az az elempár látja el a szabályozáshoz szükséges visszacsatolást, amely a próbatest közepén helyezkedik el. A további három a hőmérséklet eltérésének mérésére szolgál (5. ábra). A próbatestek befogása a fizikai szimulátor munkaterében réz szorítókkal történik, a 4. ábra b) részletének megfelelően [16] [17].

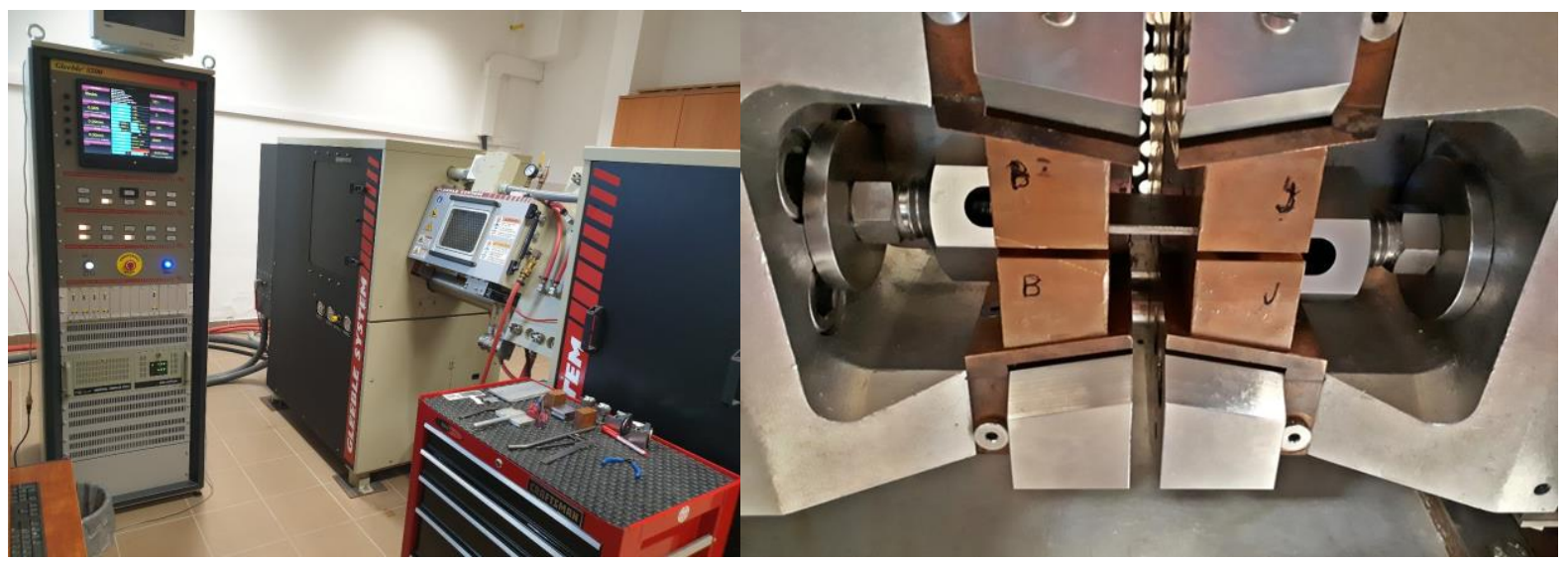

a)

b)

4. ábra. a) Gleeble 3500 fizikai szimulátor, b) A szimulátor munkatere a befogott próbatesttel.

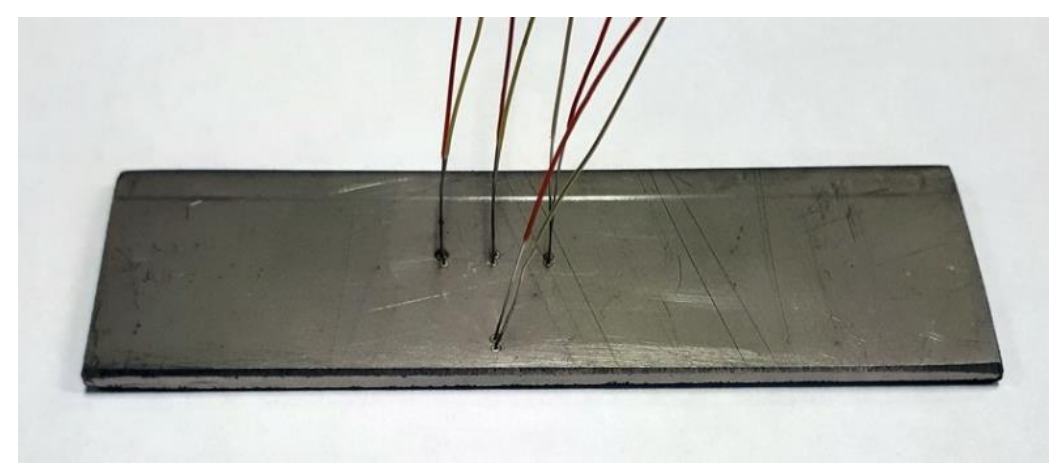

5. ábra. A vizsgált próbatest a felhegesztett termoelemekkel. 


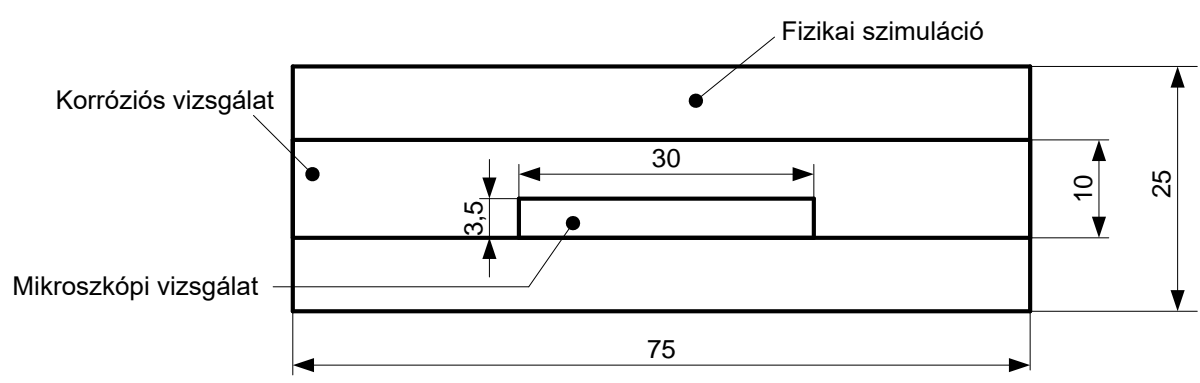

6. ábra. A fizikai szimulációs, a korróziós és a mikroszkópi vizsgálatokhoz használt próbadarabok és próbatestek geometriája (lemezvastagság: $3 \mathrm{~mm}$ ).

A fizikai szimulációs hőhatásövezeti vizsgálatokhoz első lépésben meg kell határozni az elemezni kívánt hőhatásövezeti sáv csúcshőmérsékletét. Ezt követően a szoftverben (a Rykalin-modellek esetén) a hőciklus előállításához a vonalenergia vagy pedig a t $_{\text {.5/5 }}$ hülési idő megadása szükséges. Jelen kísérleti munka során a t8,5/5 hülési idő megadása mellett döntöttünk, abból a célból, hogy ezáltal az eredmények jobban általánosíthatók több konkrét hegesztési feladathoz, mivel a hülési idő a lemezvastagság és az előmelegítési/rétegközi hőmérséklet függvényében igény esetén átszámítható konkrét vonalenergia értékekre. A vizsgálatokhoz a hülési időket az adott lemezvastagság hegesztésénél alkalmazható hegesztési paraméter tartományokból kiindulva választottuk meg. A három hülési idővel egy kisebb, egy közepes és egy nagy értéket adó paraméter csoportot kívántunk megjeleníteni.

A csúcshőmérsékletek kiválasztásánál két értéket határoztunk meg. Egyik esetben a hegesztett kötésekben az összeolvadási vonal mentén, az olvadásponthoz közeli $1250^{\circ} \mathrm{C}$-ot választottuk, ami durvaszemcsés szövetszerkezetü hőhatásövezeti sávot eredményez, míg a másik alkalmazott csúcshőmérséklet $950^{\circ} \mathrm{C}$ volt, ami a szenzibilizációs hőmérséklet tartomány felső határa.

A t t8,5/5 hülési időket a valós hegesztési kísérletek során előforduló értékekre választottuk, $60 \mathrm{~s}$ és $120 \mathrm{~s}$ értékre, valamint a nagyobb csúcshőmérséklet esetén egy $30 \mathrm{~s}$ hülési idejű hőciklust is lefuttattunk. A kísérleti tervet a 2. táblázat tartalmazza.

2. táblázat. Az alkalmazott höciklusok hömérséklet-idő paraméterei.

\begin{tabular}{|c|c|c|}
\hline Próbatest sorszám & $\mathbf{T}_{\mathbf{m a x}}{ }^{\circ} \mathbf{C}$ & $\mathbf{t}_{\mathbf{8}, \mathbf{5} / \mathbf{5}}, \mathbf{S}$ \\
\hline 1 & 1250 & 30 \\
\hline 2 & 1250 & 60 \\
\hline 3 & 1250 & 120 \\
\hline 4 & 950 & 30 \\
\hline 5 & 950 & 60 \\
\hline
\end{tabular}

A 7. ábrán egy $1250{ }^{\circ} \mathrm{C}$ csúcshőmérséklethez és $\mathrm{t}_{8,5 / 5}=30 \mathrm{~s}$ hủlési időhöz tartozó hőciklus diagramja látható, ahol megfigyelhető, hogy a próbatest közepén elhelyezett termoelemmel mért hőmérséklet lefutás (TC1) jól követi a programozott hőmérsékletet (PTemp).

A valós hegesztett kötések a vizsgált anyagminőség esetén nem csupán a vékonylemez vastagság ( $\leq 3 \mathrm{~mm}$ ) tartományába esnek, ennél nagyobb lemezvastagságok is előfordulnak hegesztett szerkezetekben. Amennyiben a lemezvastagság meghaladja az $5 \mathrm{~mm}$-t , minden esetben célszerü többrétegü kötéskialakítást alkalmazni, fogyóelektródás védőgázos ívhegesztés esetén. 
Ebben az esetben az egymást követő varratsorok hőciklusa „áthőkezeli” a korábbi varratsorokat és azok hőhatásövezetét, aminek következtében a hőhatásövezeti zónák szövetszerkezete megváltozik, új típusú zónák is keletkeznek.

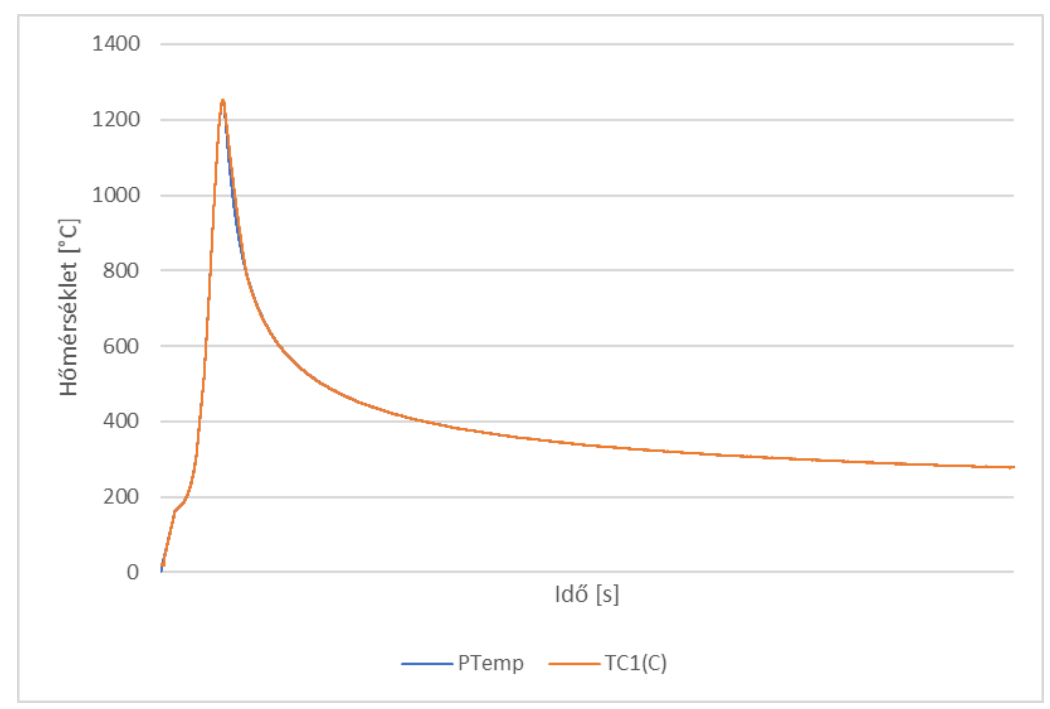

7. ábra. Szimulált hegesztési höciklus $T_{\max }=1250{ }^{\circ} \mathrm{C}$ és $t_{8,5 / 5}=30 \mathrm{~s}$ hülési idő mellett.

Ennek megfelelően a fizikai szimulációkat összetett hőciklusokkal is megvalósítottuk. Egy alkalmazott összetett hőciklus látható a 8 . ábrán, $1250{ }^{\circ} \mathrm{C}$ csúcshőmérsékletủ első, majd egy $800{ }^{\circ} \mathrm{C}$ csúcshőmérsékletű másodlagos hőciklussal. Az egymást követő hőciklusok hülési ideje minden esetben azonos volt, $30 \mathrm{~s}, 60 \mathrm{~s}$ majd $120 \mathrm{~s}$. Az összetett höciklusok paramétereit a 3. táblázat foglalja össze.

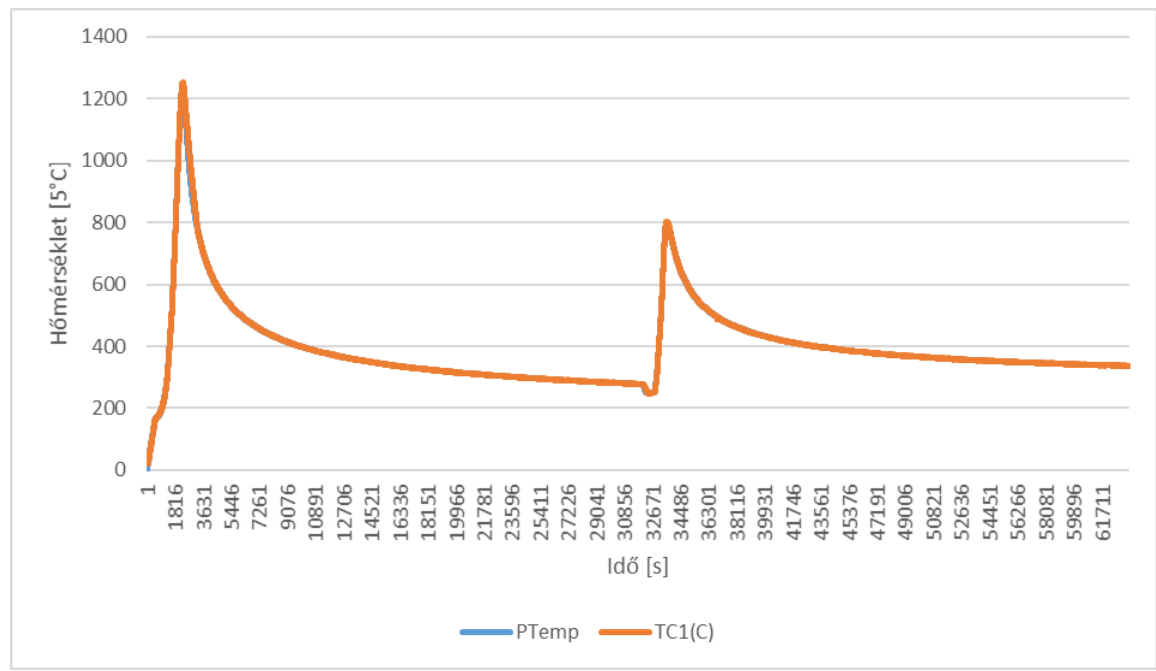

8. ábra. Szimulált hegesztési höciklus $T_{\max }=1250{ }^{\circ} \mathrm{C}$ és $800^{\circ} \mathrm{C}, t_{8,5 / 5}=30 \mathrm{~s}$ hülési idö mellett. 
3. táblázat. Az összetett höciklusok hömérséklet-idö paraméterei.

\begin{tabular}{|c|c|c|}
\hline Próbatest sorszám & $\mathbf{T}_{\max }{ }^{\circ} \mathbf{C}$ & $\mathbf{t}_{\mathbf{8}, \mathbf{5} / 5}, \mathbf{s}$ \\
\hline 6 & $1250 / 800$ & 30 \\
\hline 7 & $1250 / 800$ & 60 \\
\hline 8 & $1250 / 800$ & 120 \\
\hline
\end{tabular}

Fontos megemlíteni, hogy a bemutatott hőciklusok a próbatestek hosszának felénél elhelyezkedő keresztmetszetben érvényesek, attól már 4-5 mm-re csupán kisebb hőmérsékletek voltak mérhetők, a befogók hőelvonása miatt. Ennek megfelelően a csiszolatok keresztmetszetének közepén végeztük vizsgálatainkat.

\subsection{Korróziós vizsgálatok}

A Gleeble 3500 fizikai szimulátorral hőkezelt próbatesteket az [5] szabvány E részletének elöírásaival összhangban tettük ki korróziós igénybevételnek. A választott eljárás 16\%-os réz-rézszulfát közeget alkalmaz, amelynek előállításához $100 \mathrm{~g}$ reagens rézszulfátot $\left(\mathrm{CuSO}_{4} \cdot 5 \mathrm{H}_{2} \mathrm{O}\right)$ kell oldani $700 \mathrm{ml}$ desztillált vízben, amihez $100 \mathrm{ml}$ kénsavat kell adagolni, majd $1000 \mathrm{ml}$ mennyiségre hígítani további desztillált víz adagolásával.

A vonatkozó szabvány 5 . táblázatának megfelelően a próbatesteket mechanikus úton munkáltuk ki 10 x 75 mm méretüre (6. ábra). A vizsgálat ideje 15 óra volt, amely idő a korrozív közeg forrásától számítandó. A vizsgálati összeállítás a 9. ábrán látható.

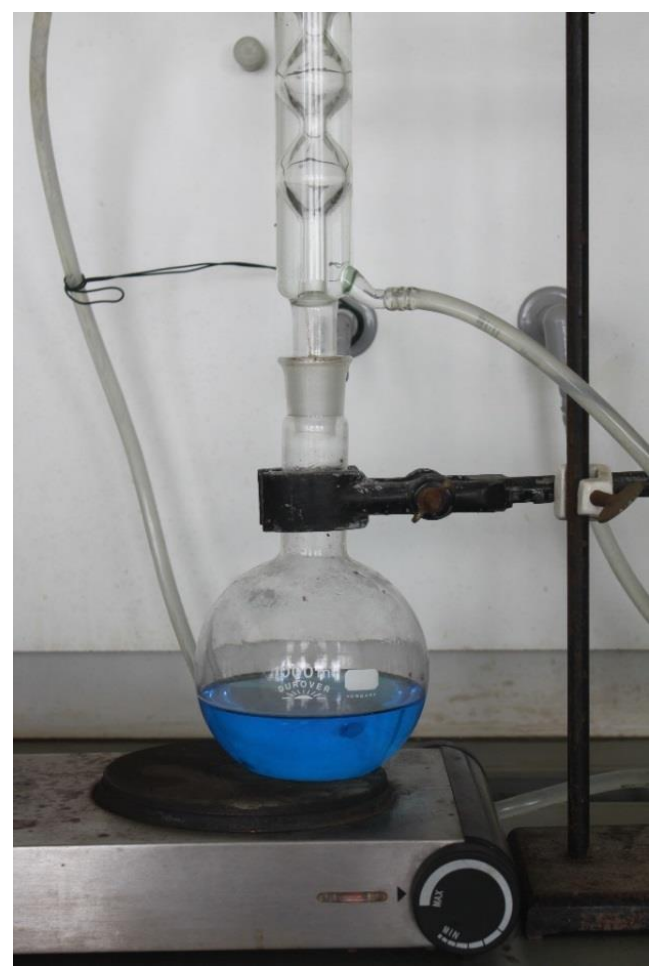

9. ábra. A korróziós vizsgálat elrendezése. 


\section{Eredmények és következtetések}

\subsection{A korróziós károsodás kimutatása egyciklusú hőbevitel esetén}

A korróziós közegben történt 15 órás fözést követően valamennyi próbatest felületét ZEISS Observer D1m optikai mikroszkópon tanulmányoztuk, a jellemző részletekről mikroszkópi felvételeket készítettünk. Az 1. jelü, $1250{ }^{\circ} \mathrm{C}$ maximális hömérsékletre hevített és $30 \mathrm{~s}$ idő alatt $850{ }^{\circ} \mathrm{C}$-ról $500{ }^{\circ} \mathrm{C}$-ra hült próbatest felületéről készült felvételt mutatja a 10. ábra. Megállapítható, hogy a különbözö hőciklussal kezelt valamennyi próbatest felülete hasonló, a szemcsehatárok jól láthatók a maródás következtében.

A korróziós közegben kezelt próbatesteket hossztengelyükkel párhuzamosan kettévágtuk úgy, hogy a szélesség irányú osztás 2/3-1/3 arányú volt. A keskenyebb részek közepéből egy $30 \mathrm{~mm}$ hosszú darabot vágtunk le. A síkköszörült, befogóban rögzített minták felületét csiszoltuk. Az ilyen módon elökészített próbatesteket ZEISS Observer D1m optikai mikroszkópon tanulmányoztuk 1000-szeres nagyításban.

Megállapítható, hogy valamennyi hőciklussal kezelt próbatest felület alatti részén szemcsehatár kimaródás figyelhető meg, de azok mélysége jellemzően csak egy-egy szemcse méretü, eloszlásuk sem egyenletes. A 2. jelü, $1250{ }^{\circ} \mathrm{C}$ maximális hőmérsékletre hevített és $60 \mathrm{~s}$ idő alatt $850{ }^{\circ} \mathrm{C}$-ról $500{ }^{\circ} \mathrm{C}$-ra hült próbatestről készült felvétel a 11. ábrán látható. A felvételen a kékes terület a vizsgált acél alapanyag, míg a szürke terület a réz befogó.

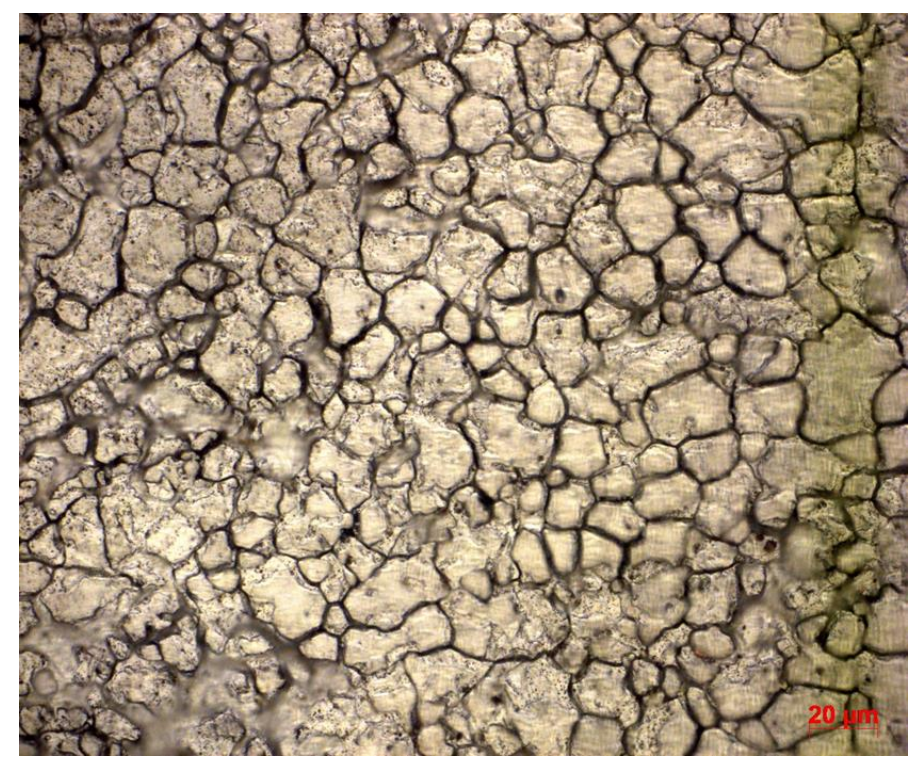

10. ábra. Az $1250^{\circ} \mathrm{C}$-ról $t_{8,5 / 5}=30 \mathrm{~s}$ hülési idővel kezelt próbatest felülete (1. próbatest).

Az [5] szabvány E részlete a korróziós károsodás kimutatására hajlító vizsgálatot ír elő. A szimulált hőciklussal kezelt, majd korróziós vizsgálatnak kitett próbatestek levágott $2 / 3$ részét hárompontos hajlítással elöhajlítottuk, majd párhuzamos nyomólapok között tovább hajlítottuk $180^{\circ}$-ig. Felületüket ZEISS Stemi 2000-C típusú sztereó mikroszkópon tanulmányoztuk 32 - 100 szoros nagyításban. Ilyen feltételek mellett a próbatestek felületén szemcsehatármenti korróziót határozottan mutató változást, felnyílást nem észleltünk.

Ennek megfelelően a kísérleteket alacsonyabb hőmérséklettartomány alkalmazásával bővítettük, az erre vonatkozó adatokat tartalmazza a 4. táblázat. 


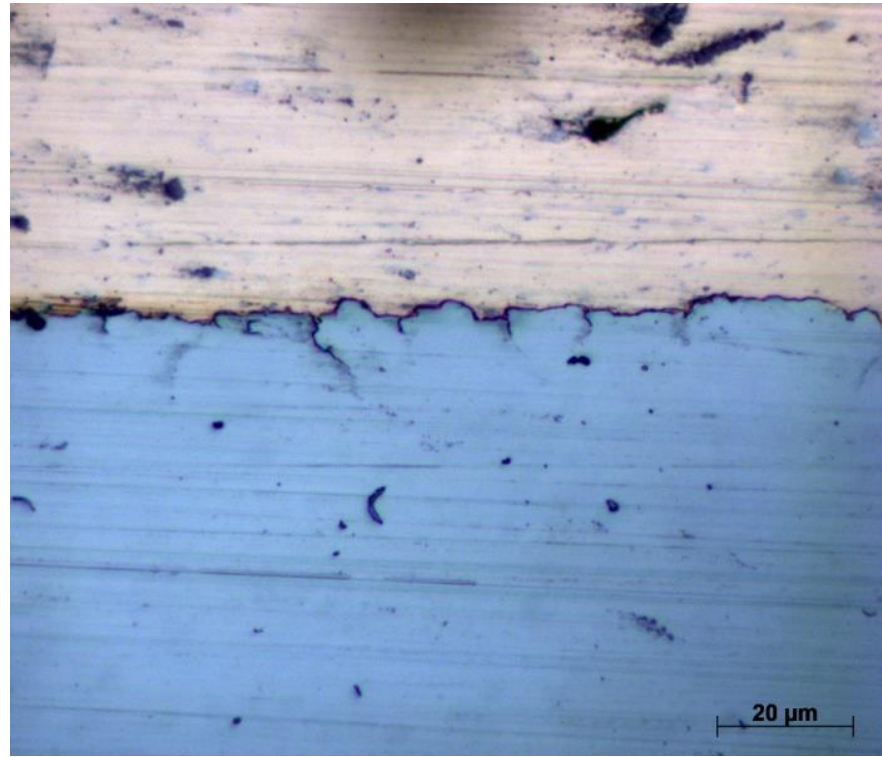

11. ábra. Az $1250{ }^{\circ} \mathrm{C}$-ról t $t_{8,5 / 5}=60 \mathrm{~s}$ hülési idővel kezelt próbatest metszetének részlete (2. próbatest).

4. táblázat. Az alkalmazott höciklusok hömérséklet-idö paraméterei alacsonyabb hömérsékleten, egy ciklus esetén.

\begin{tabular}{|c|c|c|}
\hline Próbatest sorszám & $\mathbf{T}_{\max },{ }^{\circ} \mathbf{C}$ & $\mathbf{t}_{\mathbf{8 , 5} 5 / 5}, \mathbf{s}$ \\
\hline 9 & 800 & 30 \\
\hline 10 & 800 & 60 \\
\hline 11 & 800 & 120 \\
\hline
\end{tabular}

A hőciklust követően csiszolással készítettük elő a próbatestek felületét, a korróziós közegben fözés előtt. Az újabb vizsgálatok esetében készült felvételek a 12. ábrán láthatóak. A felületről mindhárom esetben indulnak az anyag belseje felé szemcsehatármenti korróziós vonalak, azonban megállapítható, hogy a hülési idő nincs jelentős hatással ezek kialakulásának mértékére. A közepes hülés (60 s) esetén figyelhető meg jelentősebb maródás, azonban ez kisebb területre koncentrálódik.

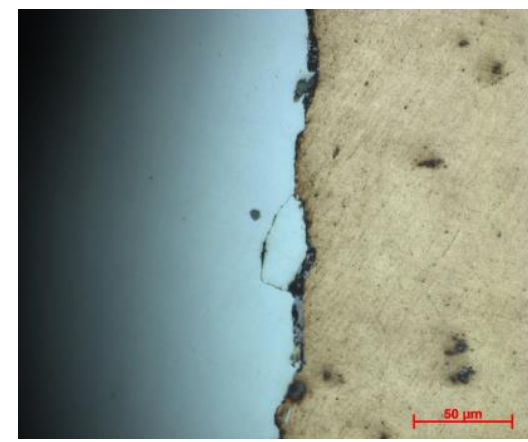

a)

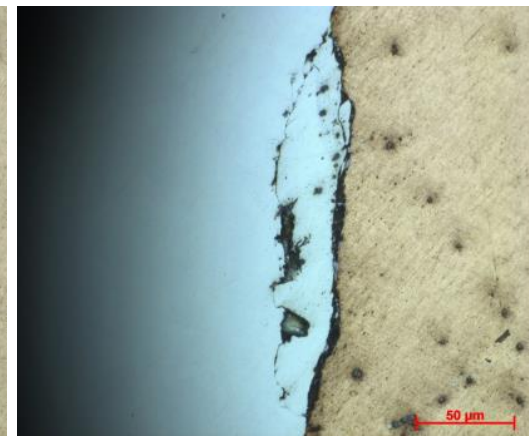

b)

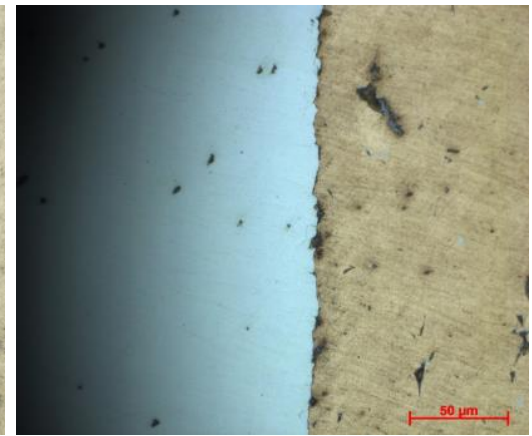

c)

12. ábra. A $800^{\circ} \mathrm{C}$-ról t $t_{8,5 / 5}=30(\mathrm{a}), 60(\mathrm{~b}), 120(\mathrm{c}) \mathrm{s}$ hülési idővel kezelt próbatestek metszeteinek részlete (9., 10., 11. próbatestek). 


\subsection{A korróziós károsodás kimutatása többciklusú hőbevitel esetén}

Ezen kísérleteknél a többciklusú szimulált hőciklust követően szintén a fent bemutatott korróziós vizsgálatot végeztük el a próbatesteken. A darabokat hossztengelyükkel párhuzamosan ismételten kettévágtuk úgy, hogy az osztás 2/3-1/3 arányú volt. A próbatestek felületéröl készült felvételeket a 13. ábra, míg a kettévágott darabok metszeteinek optikai mikroszkópos felvételeit a 14. ábra mutatja be.

A 13. ábra kapcsán fontos megjegyezni, hogy a 6. próbatest esetében $\left(\mathrm{T}_{\max }=1250^{\circ} \mathrm{C}\right.$ és $800{ }^{\circ} \mathrm{C}$, $\mathrm{t}_{8,5 / 5}=30 \mathrm{~s}$ ) nem alakult ki érzékelhető szemcsehatármenti korrózió a keresztmetszetben, a szemcsehatárokon maródást nem figyeltünk meg. Ennek lehetséges oka, hogy az $1250{ }^{\circ} \mathrm{C}$-os hevítés után történt egy ausztenites lehütés, majd ezután egy újabb $800^{\circ} \mathrm{C}$-os hevítés, amely esetében karbidkiválás már nem alakult ki.

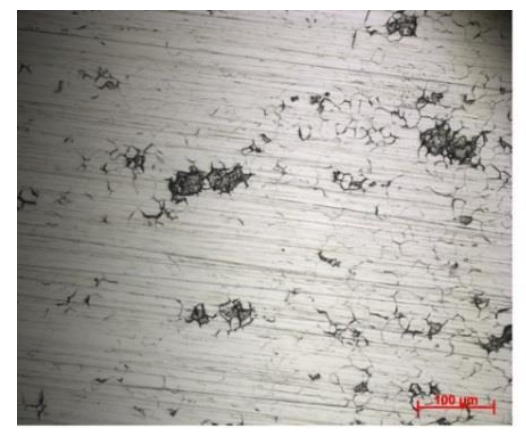

a)

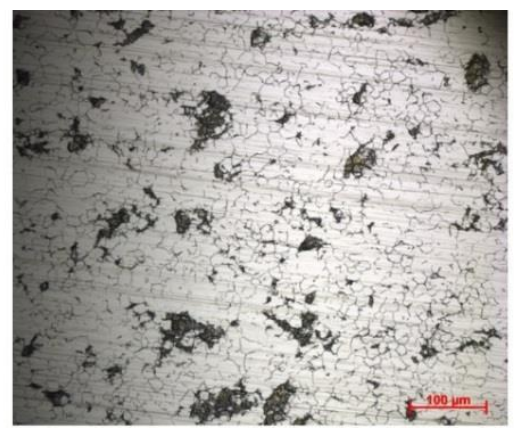

b)

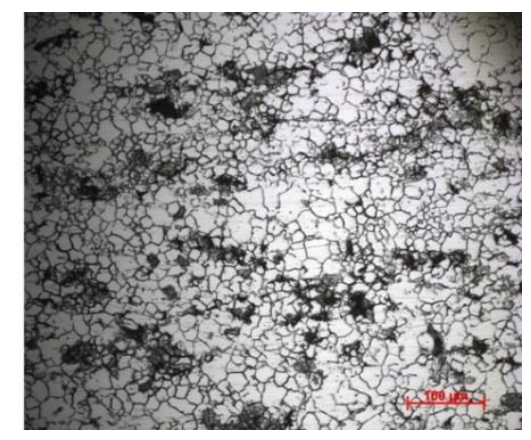

c)

13. ábra. Többciklusú höbevitelen átesett próbatestek felületei. $T_{\max }=1250{ }^{\circ} \mathrm{C}$ és $800{ }^{\circ} \mathrm{C}$, $t_{8,5 / 5}=30(a), 60(b), 120(c) s(6 ., 7 ., 8$. próbatest).

A mikrocsiszolati felvételeken megfigyelhető balról jobbra haladva, hogy a dupla hőciklus esetén a hülési idő növelése már észrevehető különbséget okozott a felületröl induló szemcsehatárokon kialakuló korróziós jelenségekben. A $60 \mathrm{~s}$ hülési idő esetén csak néhány szemcsén figyelhetők meg felület alá futó korróziós vonalak, míg a 120 s esetén szinte minden felületi szemcsehatárról indulnak ilyen vonalak, amelyek a felület alatt össze is futnak. Mélyebb szemcserétegekbe ugyanakkor ezek a korróziós vonalak nem hatolnak be.

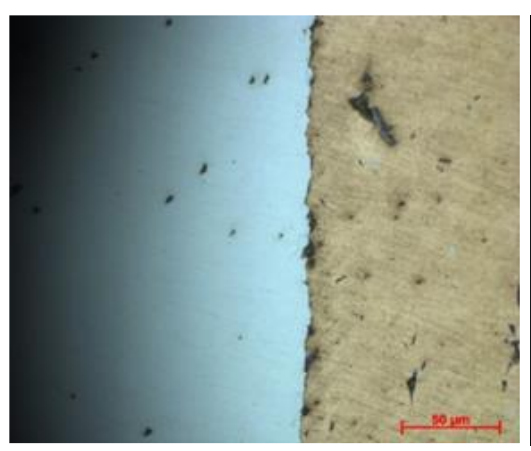

a)

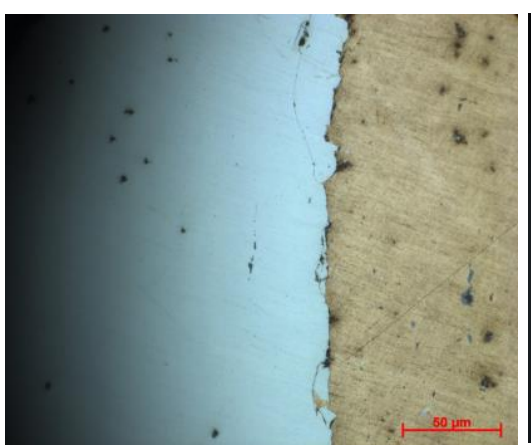

b)

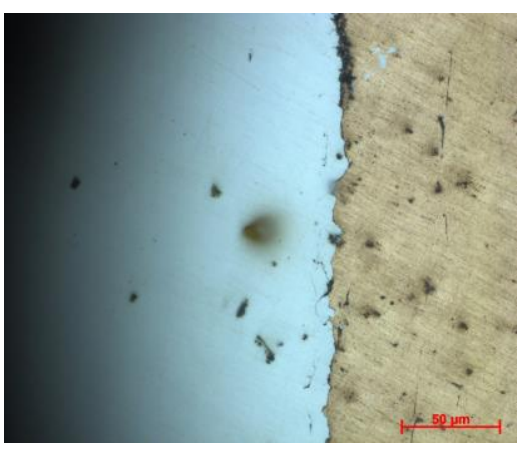

c)

14. ábra. Többciklusú höbevitelen átesett próbatestek metszeteinek részlete. $T_{\max }=1250^{\circ} \mathrm{C}$ és $800^{\circ} \mathrm{C}, t_{8,5 / 5}=30(\mathrm{a}), 60(\mathrm{~b}), 120(\mathrm{c}) \mathrm{s}(6 ., 7 ., 8$. próbatest) 


\section{6. Összefoglalás}

Az elvégzett korróziós vizsgálatok alapján az alábbi megállapítások tehetők.

Az egyrétegü varratok hatását szimuláló egyszerü (egyciklusú) hőkezelések esetén, magasabb csúcshőmérséklet $\left(1250\right.$, illetve $\left.950^{\circ} \mathrm{C}\right)$ mellett a vizsgált próbatestek felületén szemcsehatármenti korróziót határozottan mutató változást nem tapasztaltunk.

Ugyanakkor egyszerü (egyciklusú) hőkezelések esetén, alacsonyabb csúcshőmérsékletet alkalmazva $\left(800^{\circ} \mathrm{C}\right)$ a felületről már indul az anyag belseje felé szemcsehatármenti korrózió, de a hülési idő nagyságának hatása egyértelmüen nem volt kimutatható.

Összetett, a többrétegủ varratok hatását szimuláló (többciklusú) hőkezelések esetén a hűlési idő növelése már észrevehető különbséget okozott a felületről induló szemcsehatármenti korrózió mértékében. A 30 s hủlési idő esetén nem, a 60 s-nál néhány szemcsén figyelhetők csak meg felület alá futó korróziós kimaródás, míg a 120 s esetén szinte minden felületi szemcsehatáron érzékelhető korróziós elváltozás. Mélyebb anyagrétegben ugyanakkor szemcsehatármenti korrózió már nem tapasztalható. Megfigyelhető tehát, hogy minél hosszabb volt a hủlési idő, annál markánsabban látszódnak az egyes sorozatoknál a szemcsehatárok kimaródásai.

\section{Köszönetnyilvánítás}

A cikkben ismertetett kutató munka az EFOP-3.6.1-16-2016-00011 jelü „Fiatalodó és Megújuló Egyetem - Innovatív Tudásváros - a Miskolci Egyetem intelligens szakosodást szolgáló intézményi fejlesztése" projekt részeként - a Széchenyi 2020 keretében - az Európai Unió támogatásával, az Európai Szociális Alap társfinanszírozásával valósul meg. Továbbá köszönet illeti Prof. Dr. Török Tamás egyetemi tanárt a korróziós vizsgálatok elvégzéséért.

\section{Irodalom}

[1] Szunyogh, L.: Hegesztés és rokon technológiák kézikönyv, Gépipari Tudományos Egyesület, 2007

[2] Bagyinszki, Gy., Kovács, M.: Gépipari alapanyagok és félkész gyártmányok, Anyagismeret, Tankönyvmester Kiadó, Budapest, 2010

[3] Verő, J., Káldor, M.: Fémtan, Tankönyvkiadó, Budapest, 1977

[4] Chater, J.: What prospects for stainless steels in 2016? Stainless Steel World, 2016, January/February, 1-5.

[5] McGuire, M. F.: Stainless steels for design engineers, ASM International, 2008 https://doi.org/10.31399/asm.tb.ssde.9781627082860

[6] Bödök, K.: Az ötvözetlen, gyengén és erösen ötvözött szerkezeti acélok korrózióállósága, különös tekintettel azok hegeszthetöségére, CorWeld, 1997

[7] Zheng-Fei, H.: Heat-resistant steels, microstructure evolution and life assessmentin power plants, School of Materials Science and Engineering Tongji University, Shanghai, China, 2012

[8] Khatak, H. S., Raj, B.: Corrosion of austenitic stainless steels, India, 2002 https://doi.org/10.1533/9780857094018

[9] Balogh, A., Béres, L.: Új eredmények a melegszilárd acélok vegyes kötéseinek hegesztése terén, GÉP, LXII. 4. (2011) pp. 29-32.

[10] Zorkóczy, B.: Metallográfia és anyagvizsgálat, Tankönyvkiadó, Budapest, 1975 
[11] Fujita, T.: Advances in 9-12\% Cr heat resistant steels for power plant, 2002 In: Proceedings of the 3rd Conference on Advances in Material Technology for Fossil Power Plants, Institute of Materials, London (UK), pp. 49-57.

[12] Varbai, B., Gál, I., Fábián, E. R., Májlinger, K.: Ausztenites és duplex korrózióálló acélok vegyes kötéseinek korróziós tulajdonságai, Bányászati és Kohászati Lapok - Kohászat, 151 (1) (2018) pp. 36-40.

[13] Májlinger, K., Szabó, P. J.: Intercrystalline cracking of austenitic steel during brazing, Materials Science Forum, 729 (2013) pp. 442-447. https://doi.org/10.4028/www.scientific.net/MSF.729.442

[14] Dobránszky, J., Varbai, B.: A króm-mangán ötvözésü ausztenites acélok és hegesztésük, Hegesztéstechnika, 27(3) (2016) pp. 33-38.

[15] ASTM A262 Practice A, B, C, E and F Intergranular Corrosion Testing

[16] Lukács, J., Nagy, Gy., Harmati, I., Koritárné, F. R., Kuzsella, Lné K. Zs.: Szemelvények a mérnöki szerkezetek integritása témaköréböl, Miskolci Egyetem, Miskolc, 2012

[17] Balogh, A., Lukács, J., Török, I.: Hegeszthetőség és a hegesztett kötések tulajdonságai, Kutatások jármüipari acél és alumínium ötvözet anyagokon, Miskolc, 2015 